\title{
Studies on inheritance of resistance and allelic relationships for strain 2 of pigeonpea sterility mosaic pathogen
}

\author{
By T SRINIVAS ${ }^{1,2 *}, \mathrm{M} \mathrm{V} \mathrm{REDDY}^{1}, \mathrm{~K} \mathrm{C} \mathrm{JAIN}^{1}$ and M S S REDDY ${ }^{2}$ \\ ${ }^{1}$ ICRISAT Asia Center, Patancheru 502 324, Andhra Pradesh, India; ${ }^{2}$ Andhra \\ Pradesh Agricultural University, Hyderabad 500 030, Andhra Pradesh, India
}

(Accepted 7 January 1997)

\begin{abstract}
Summary
Inheritance of resistance and allelic relationships were studied in three resistant pigeonpea sources for strain 2 of sterility mosaic pathogen. The resistant genotypes (ICP 7035, ICP 7349 and ICP 8850) were crossed with susceptible genotypes (BDN1 and LRG30) to determine the inheritance of resistance. The resistant and susceptible genotypes were also crossed among themselves to obtain information on their allelic relationships. Parents, $F_{1}$ and $F_{2}$ generations were sown in pots and screened using infector-hedge technique. Observations in parents, $F_{1}$ and $\mathrm{F}_{2}$ generations, indicated dominance of resistance in certain crosses and the dominance of susceptibility in others. Disease reaction appeared to be governed by two independent non-allelic genes, with at least three multiple alleles, at one of the loci.
\end{abstract}

Key words: Cajanus cajan, pigeonpea, sterility mosaic, inheritance, strain, resistance, susceptibility

\section{Introduction}

Sterility mosaic, an important disease of pigeonpea, is known to occur in almost all the major pigeonpea growing areas of India (Kannaiyan et al., 1984) and at times can cause yield losses up to $95 \%$ (Reddy \& Nene, 1981). An annual loss of 205000 tonnes of grains valued at US $\$ 76.9$ millions is estimated from the sterility mosaic disease (Kannaiyan et al., 1984). It was first reported from Pusa in Bihar, India (Mitra, 1931) and is presently a serious problem in north eastern and southern states of India. The disease is characterised by proliferation, mosaic symptoms, cessation of reproductive growth and a reduction in the size of the leaflets (Kandaswamy \& Ramakrishnan, 1960). It is transmitted by an eriophyid mite, Aceria cajani Channabasavanna (Seth, 1962). Chemical methods of control, while effective, are not considered economical (Nene et al., 1989). Therefore, breeding of resistant varieties, recognised as the most effective and economic method of reducing crop losses, has received high priority for the disease.

Development of pigeonpea cultivars resistant to the disease was first reported by Alam (1931). Systematic resistance breeding was later initiated at the International Crops Research 
Institute for the Semi-Arid Tropics (ICRISAT) in 1975, and several resistant and tolerant source(s) for the disease were identified (Amin et al., 1993; Nene, Kannaiyan, Reddy \& Remanandan, 1981). The genetics of resistance for the disease was also worked out (Sharma, Gupta, Rai \& Reddy, 1984; Singh et al., 1983). However, the task of developing resistant varieties has been complicated in view of the reported variability in the pathogen. The presence of strains of SM pathogen of varying virulence was reported by Nene et al. (1989) based on the results of multi-location pigeonpea trials. Lines resistant at ICRISAT, Patancheru, Andhra Pradesh became susceptible when grown at other locations within India. A comprehensive study of variability in the sterility mosaic pathogen (Reddy et al., 1993), using a set of seven differentials, at nine different locations in India, revealed the occurrence of five different variants of the sterility mosaic pathogen of pigeonpea in India.

The dynamic nature of the sterility mosaic pathogen has warranted the identification and use of strain-specific sources of resistance in the crop improvement programme. Further, it has also necessitated studies on genetics of strain-specific resistance to aid resistance breeding programmes. The earlier studies on genetics of resistance for the disease (Singh et al., 1983; Sharma et al., 1984) have very little significance in the wake of reports on the existence of several strains of the pathogen. Hence, the present investigation was undertaken to elucidate the inheritance of resistance and allelic relationship of a few resistant sources for strain 2 of the sterility mosaic pathogen.

\section{Materials and Methods}

A set of 153 genotypes, earlier reported as resistant or tolerant (Nene et al., 1981) were screened at the ICRISAT Asia Center, Patancheru during May 1994, against strain 2 of the sterility mosaic pathogen, identified by Reddy, Raju \& Nene (1991). The screening was carried out using the infector-hedge technique (Nene \& Reddy, 1976). Ten seeds of each genotype were sown in plastic pots of $15 \mathrm{~cm}$ diameter filled with alfisols $(60 \%$ sand, $33 \%$ clay and $7 \%$ silt) and placed beside the infector-hedge. Genotypes with less than $20 \%$ disease incidence were re-evaluated, in three replications, to identify promising resistant sources for the strain. Genotypes were classified as resistant when disease incidence was less than $10 \%$.

Three genotypes (ICP 7035, ICP 7349 and ICP 8850) of medium to late maturity duration, resistant (with no apparent symptoms) to the strain, were selected as resistant parents. These were crossed with two susceptible (severe mosaic symptoms) parents, BDN 1 and LRG 30. The resistant and susceptible parents were also crossed among themselves, to obtain information on allelic relationships.

The resistant parents were sown in four sets at intervals of 15 days in $30 \mathrm{~cm}$ pots and placed beside the infector-hedge, while the susceptible parents were raised under disease-free conditions. Confirmed resistant plants were used for crossing with the susceptible parents and sufficient $F_{1}$ seed was obtained in each cross combination. Part of the $F_{1}$ seed was advanced to the $F_{2}$ generation during the rainy season of 1994 . The $F_{1}$ plants were selfed by covering them with bee-proof nylon cages. Flower initiation, flower colour, pod colour, seed colour, seed size and other contrasting characters among the parents were used as markers to check the identity of $F_{1}$ plants. Only true $F_{1}$ 's were advanced to $F_{2}$.

Five parents, $10 \mathrm{~F}_{1}$, and $10 \mathrm{~F}_{2}$ of the resistant $\times$ susceptible (six), resistant $\times$ resistant (three) and susceptible $\times$ susceptible (one) cross combinations were screened against the strain, during May-December 1995, for their disease reaction using the infector-hedge technique (Nene \& Reedy, 1976). Seedlings were raised in $15 \mathrm{~cm}$ pots with 10 seedlings per pot. The susceptible control, ICP 8863 , was included at frequent intervals, to monitor disease spread. Observations on disease reaction were recorded at 75 days after sowing. The plants 
Table 1. Reaction of parents, $F_{1}$ and $F_{2}$ generations of the resistant $\times$ susceptible crosses of pigeonpea for strain 2 of sterility mosaic pathogen at ICRISAT Asia Center, Patancheru, Andhra Pradesh, India

\begin{tabular}{|c|c|c|c|c|c|c|c|}
\hline \multirow[b]{2}{*}{ Generation } & \multirow[b]{2}{*}{ Total plants } & \multicolumn{2}{|c|}{ Observed frequencies } & \multicolumn{2}{|c|}{ Expected frequencies } & \multirow[b]{2}{*}{$\begin{array}{l}\text { Ratio } \\
R: S\end{array}$} & \multirow[b]{2}{*}{ Probability } \\
\hline & & $\begin{array}{c}\text { Resistant } \\
\text { plants (R) }\end{array}$ & $\begin{array}{l}\text { Susceptible } \\
\text { plants (S) }\end{array}$ & $\begin{array}{l}\text { Resistant } \\
\text { plants (R) }\end{array}$ & $\begin{array}{c}\text { Susceptible } \\
\text { plants (S) }\end{array}$ & & \\
\hline \multicolumn{8}{|c|}{$\mathrm{CP} 7035 \times \mathrm{BDN} 1$} \\
\hline $\mathrm{F}_{1}$ & 10 & 10 & - & 10 & - & - & - \\
\hline $\mathrm{F}_{2}$ & 248 & 199 & 49 & 186 & 62 & $3: 1$ & $0.30-0.50$ \\
\hline \multicolumn{8}{|c|}{ CP $7035 \times$ LRG 30} \\
\hline $\mathrm{F}_{1}$ & 12 & 12 & - & 12 & - & - & - \\
\hline $\mathrm{F}_{2}$ & 360 & 209 & 151 & 202.5 & 157.5 & $9: 7$ & $0.30-0.50$ \\
\hline \multicolumn{8}{|c|}{ CP $7349 \times$ BDN 1} \\
\hline $\mathrm{F}_{1}$ & 8 & 8 & - & 8 & - & - & 一 \\
\hline $\mathrm{F}_{2}$ & 450 & 329 & 121 & 337.5 & 112.5 & $3: 1$ & $0.30-0.50$ \\
\hline \multicolumn{8}{|c|}{ CP $7349 \times$ LRG 30} \\
\hline$F_{1}$ & 9 & 9 & - & 9 & - & - & - \\
\hline $\mathrm{F}_{2}$ & 327 & 195 & 132 & 183.94 & 143.06 & $9: 7$ & $0.20-0.30$ \\
\hline \multicolumn{8}{|c|}{$\mathrm{CP} 8850 \times \mathrm{BDN} 1$} \\
\hline$F_{1}$ & 12 & - & 12 & - & 12 & - & - \\
\hline$F_{2}$ & 398 & 87 & 311 & 99.5 & 298.5 & $1: 3$ & $0.10-0.20$ \\
\hline \multicolumn{8}{|c|}{ CP $8850 \times$ LRG 30} \\
\hline$F_{1}$ & 14 & - & 14 & - & 14 & _- & - \\
\hline $\mathrm{F}_{2}$ & 220 & 49 & 171 & 41.25 & 178.75 & $3: 13$ & $0.10-0.20$ \\
\hline
\end{tabular}

were classified as resistant (no apparent symptoms) and susceptible (severe mosaic symptoms). The chi-square method (Snedecor \& Cochran, 1967) was used to test the goodness of fit of the segregating populations with the expected phenotypic ratios.

\section{Results and Discussion}

The susceptible control (ICP 8863), planted along with the test materials (five parents, $10 \mathrm{~F}_{1}$ and $10 \mathrm{~F}_{2}$ ) exhibited $100 \%$ infection indicating good spread of the disease. ICP 7035 , ICP 7349 and ICP 8850 were recorded as $100 \%$ resistant with no apparent symptoms, while BDN1 and LRG 30 exhibited severe mosaic symptoms.

The reactions of $F_{1}$ and $F_{2}$ generations of the resistant $\times$ susceptible crosses are presented in Table 1. Dominance of resistance over susceptibility was observed in the $F_{1}$ generation of resistant $\times$ susceptible crosses involving the resistant parents ICP 7035 and ICP 7349 , while susceptibility was dominant in the $F_{1}$ generation of resistant $\times$ susceptible crosses involving the resistant parent ICP 8850 . The dominance of susceptibility over resistance has also been reported by Singh et al. (1983) and Sharma et al. (1984). A variation in the dominance relationships of the disease reaction with the cross involved was also noticed by Sharma et al. (1984) similar to the findings of the present study.

In the $\mathrm{F}_{2}$ generation, the crosses of the resistant parents, ICP 7035 and ICP 7349 with the susceptible parent BDN1 segregated in the ratio 3 resistant : 1 susceptible, while crosses with the susceptible parent LRG30 segregated in a ratio of 9 resistant : 7 susceptible. However, in the $\mathrm{F}_{2}$ generation of the crosses involving the resistant parent ICP 8850 and the susceptible BDN1, a ratio of 1 resistant : 3 susceptible was obtained while, in combination with the susceptible parent LRG30, a ratio of 3 resistant : 13 susceptible was obtained. This suggested that ICP 7035, ICP 7349 and ICP 8850 differed with the susceptible BDN1 in respect of a 
Table 2. Reaction of $F_{1}$ and $F_{2}$ generations of the resistant $\times$ resistant and susceptible $\times$ susceptible crosses of pigeonpea for strain 2 of sterility mosaic pathogen at ICRISAT Asia Center, Patancheru, Andhra Pradesh, India

\begin{tabular}{|c|c|c|c|c|c|c|}
\hline \multicolumn{4}{|c|}{ Observed frequencies } & \multicolumn{2}{|c|}{ Expected frequencies } & \\
\hline eneration & Total plants & $\begin{array}{l}\text { Resistant } \\
\text { plants }(R)\end{array}$ & $\begin{array}{l}\text { Susceptible } \\
\text { plants }(S)\end{array}$ & $\begin{array}{l}\text { Resistant } \\
\text { plants }(\mathrm{R})\end{array}$ & $\begin{array}{c}\text { Susceptible } \\
\text { plants }(S)\end{array}$ & $\begin{array}{l}\text { Ratio } \\
\text { R : S }\end{array}$ \\
\hline
\end{tabular}

Resistant $\times$ Resistant

ICP $7035 \times$ ICP 7349

$\begin{array}{rr}F_{1} & 22 \\ F_{2} & 297 \\ \text { ICP } 7035 \times 1 C P 8850 \\ F_{1} & 14 \\ F_{2} & 457 \\ \text { ICP } 7349 \times \text { ICP } 8850 \\ F_{1} & 18 \\ F_{2} & 339\end{array}$

Susceptible $\times$ Susceptible $\mathrm{BDNI} \times \mathrm{LRG} 30$

$\begin{array}{lr}\mathrm{Fi}_{1} & 20 \\ \mathrm{~F}_{2} & 472\end{array}$

20
472

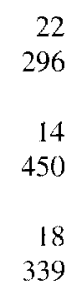

22

296

14

450

18

339

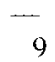

-
-7
-
11

20

463

22
297
14
457

18
350

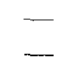

20

472

single gene pair, while with LRG30, they differed in respect of at least two gene pairs. Singh et al. (1983) and Sharma et al. (1984) also reported a similar variation between different crosses in the number of genes governing resistance. Singh et al. (1983) reported the involvement of two genes in crosses involving the resistant parents Pant A3 and ICP 6999, and three genes in crosses involving the resistant parents ICP 3783, ICP 7035 and ICP 7119 with the susceptibles Pant A2, UPAS120 and T21. However, Sharma et al. (1984) reported the involvement of two genes governing resistance in ICP 7035 and tolerance in ICP 2376 in cross combinations with the susceptible parent BDN1.

The $\mathrm{F}_{2}$ segregation ratios of 9 resistant: 7 susceptible in resistant $\times$ susceptible crosses involving the resistant parents ICP 7035 and ICP 7349 with LRG30 indicated the presence of two independent non-allelic gene pairs exhibiting complementary gene action. The $\mathrm{F}_{2}$ segregation ratio of 3 resistant: 13 susceptible in ICP $8850 \times$ LRG30 also indicated the presence of two independent non-allelic gene pairs. The ratios can be explained on the basis of the presence of multiple alleles governing the resistance trait for the strain. The hypothesis of duplicate genes and multiple alleles is combined to explain the disease reactions observed in $F_{1}$ combinations and segregation in $F_{2}$. A resistance reaction occurs when resistant alleles are present at the two loci while, susceptibility is observed when the susceptible alleles are present even at one locus. At least three allelic forms are present at one of the loci with the dominance relationship of $a_{1}>a_{2}>a_{3}$. The alleles $a_{1}$ and $a_{3}$ are assumed to be responsible for the resistance reaction, while the allele $a_{2}$ results in a susceptible reaction. Thus, ICP 7035 and ICP 7349 appear to possess the $a_{1}$ allele for resistance $\left(a_{1} a_{1} B B\right)$, while ICP 8850 possesses the $a_{3}$ allele for resistance $\left(a_{3} a_{3} B B\right)$. The susceptible parent BDN 1 appears to possess the $a_{2}$ allele for susceptibility with the genetic constitution $a_{2} a_{2} B B$, while LRG30 appeared to have $a_{2} a_{2} b b$ genotypic constitution. This would explain the differential reactions of the $F_{1}$ 's and $F_{2}$ 's observed in the resistant $\times$ susceptible crosses.

The $F_{1}$ 's of all resistant $\times$ resistant crosses (Table 2) were resistant, while the $F_{1}$ of susceptible $\times$ susceptible cross (Table 2) was susceptible. Further, no segregation was observed in the $F_{2}$ generation of either resistant $\times$ resistant or susceptible $\times$ susceptible crosses. This indicated the role of the same loci for resistance and susceptibility in the parents 
studied. The few resistant plants recorded in the susceptible $\times$ susceptible cross combinations could be escapes.

A further study to analyse and characterise all available resistant sources for their allelic relationship with regard to strain 2 of the sterility mosaic pathogen would be of immense value in breeding resistant cultivars with a broad genetic base. It would also be useful to investigate the genetics of the host-pathogen interaction by including different strains of the pathogen. Attempts should also be made to combine different alleles to diversify the genetic composition of the lines with regard to the resistance genes. Further, it would be desirable to develop a series with various allelic combinations in a common genetic background to be used as a tester to facilitate proper identification of alleles in different genotypes.

\section{Acknowledgements}

The senior author is grateful to the Council of Scientific and Industrial Research (CSIR), New Delhi, India, for the award of Senior Research Fellowship. He is also thankful to ICRISAT Asia Center, Patancheru, India, for providing field and greenhouse facilities for carrying out the research.

This paper was submitted as JA No. 1928 by the International Crops Research Institute for the Semi-Arid Tropics (ICRISAT).

\section{References}

Alam M. 1931. Arhar sterililty. Proceedings of Twentieth Annual Meeting of Indian Science Congress, Poona, Section Agriculture 43:15-16.

Amin K S, Reddy M V, Nene Y L, Raju T N, Pratibha Shukla, Zote K K, Arjunan G, Bendre J N, Rathi Y P S, Sinha B K, Gupta R P, Anilkumar T B, Chauhan V B, Gurdeep Singh, Jha D K, Kausalya Gangadharan. 1993. Multi-location evaluation of pigeonpea (Cajanus cajan) for broad based resistance to sterility mosaic disease in India. Indian Journal of Agricultural Sciences 63:542546.

Kandaswamy T K, Ramakrishnan K. 1960. An epiphytotic of pigeonpea sterility mosaic at Coimbatore. Madras Agricultural Journal 47:440-441.

Kannaiyan J, Nene Y L, Reddy M V, Ryan J G, Raju T N. 1984. Prevalence of pigeonpea diseases and associated crop losses in Asia, Africa and the Americas. Tropical Pest Management 30:62-71.

Mitra M. 1931. Report of the Imperial Mycologist. Scientific Reports of Agricultural Research Institute, Pusa, 1929-30, Pusa, India, pp. 58-71.

Nene Y L, Reddy M V. 1976. Screening for resistance to sterility mosaic of pigeonpea. Plant Disease Reporter 60:1034-1036.

Nene Y L, Kannaiyan J, Reddy M V, Remanandan P. 1981. Sources of resistance to selected Pigeonpea diseases. Pulse Pathology Progress Report 16. Patancheru, Andhra Pradesh, India: Legumes Program, ICRISAT (Limited distribution).

Nene Y L, Reddy M V, Beniwal S P S, Mahmood M, Zote K K, Singh R N, Sivaprakasam K. 1989. Multi-locational testing of pigeonpea for broad-based resistance to sterility mosaic in India. Indian Phytopathology 42:444-448.

Reddy M V, Nene Y L. 1981. Estimation of yield loss in pigeonpea due to sterility mosaic. In Proceedings of International Workshop on Pigeonpeas. 2:15-19 December 1980, ICRISAT Center, Patancheru, Andhra Pradesh, India, pp. 305-312.

Reddy M V, Raju T N, Nene Y L. 1991. Appearance of a new strain of pigeonpea sterility mosaic pathogen. International Pigeonpea Newsletter 14:22-23.

Reddy M V, Raju T N, Nene Y L, Ghanekar A M, Amin K S, Arjunan G, Astaputre J V, Sinha B K, Muniyappa V, Reddy S V, Gupta R P, Gangadharan K. 1993. Variability in sterility mosaic pathogen in pigeonpea in India. Indian Phytopathology 46:206-212. 
Seth M L. 1962. Transmission of pigeonpea sterility by an eriophyid mite. Indian Phytopathology 15:225-227.

Sharma D, Gupta S C, Rai G S, Reddy M V. 1984. Inheritance of resistance to sterility mosaic disease in pigeonpea I. Indian Journal of Genetics and Plant Breeding 44:84-90.

Singh B V, Pandya B P, Gautam P L, Beniwal S P S, Pandey M P. 1983. Inheritance of resistance to sterility mosaic virus in pigeonpea. Indian Journal of Genetics and Plant Breeding 43:487-493.

Snedecor W G, Cochran G W. 1967. Statistical Methods. New Delhi, India: Oxford \& IBH Publishing Co. pp. 228-253.

(Received 26 June 1996) 